\title{
Como se toca o baião: combinações de elementos musicais no repertório de Luiz Gonzaga ${ }^{1}$
}

\author{
Almir Côrtes (UNICAMP, Campinas-SP) \\ almircortes@gmail.com
}

Resumo: Este trabalho busca ilustrar e explicar combinações entre elementos musicais presentes na estilização do baião, operada pelo compositor, instrumentista e cantor Luiz Gonzaga (1912-1984) entre as décadas de 1940 e 1950. Tal apreciação crítica visa sua aplicação na interpretação, composição, arranjo, análise musical e improvisação, e pode contribuir para mapear a reutilização e ressignificação de elementos estético-musicais relacionados ao baião em diferentes momentos e cenários da música brasileira.

Palavras-chave: Luiz Gonzaga e o baião; práticas interpretativas da música nordestina; apreciação musical.

\section{How to play baião: combinations of musical elements in the repertoire of Luiz Gonzaga}

Abstract: This study aims at illustrating and explaining certain combinations of musical elements used in the stylization of baião by Brazilian composer, instrumentalist and singer Luiz Gonzaga (1912-1984) between the decades of 1940 and 1950. This critical appreciation provides elements to be applied in the fields of interpretation, composition, arrangement, musical analysis and improvisation, and may contribute to identify the reuse and reinterpretation of aesthetical and musical elements related to baiõo in different times and scenes of Brazilian music.

Keywords: Luiz Gonzaga and baiõo; practice of northeastern Brazilian music; musical appreciation.

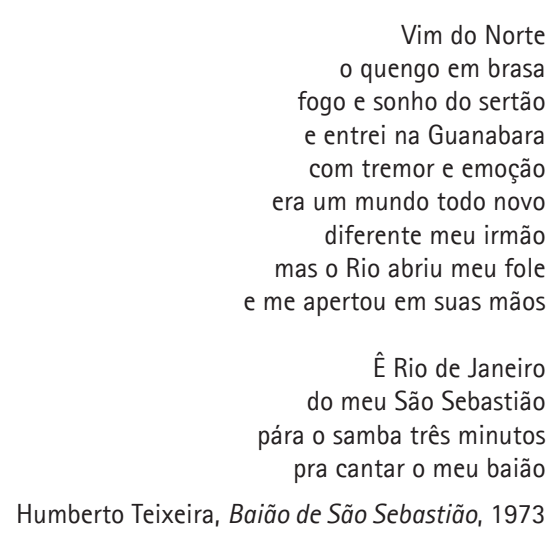

1. Introdução

A atuação do sanfoneiro e cantor pernambucano Luiz Gonzaga (1912-1984) foi fundamental para que o baião se tornasse um segmento da indústria fonográfica a partir da década de 1940. 0 músico iniciou suas gravações em disco como solista, atuando principalmente dentro do universo do choro. Entre 1941, ano da primeira gravação, e 1945 quando registrou pela primeira vez sua voz na música Dança Mariquinha de Luiz Gonzaga/Miguel Lima, Gonzaga gravou cerca de 30 discos de 78rpm pela RCA Victor. Todos esses discos portavam gravações no formato instrumental, contendo um repertório de choros, valsas, polcas, mazurcas, marchas e algumas designações pitorescas como "picadinho" e "chamego" 2. Destacam-se nesse periodo as gravações de Apanhei-te cavaquinho e Escorregando, de autoria de Ernesto Nazareth, e dos choros Treze de Dezembro e Araponga ${ }^{3}$, de autoria do próprio Gonzaga ${ }^{4}$. 
A partir de 1945, o artista passa a revezar entre gravações com voz e instrumentais. Porém, as gravações instrumentais vão ficando cada vez mais escassas e as canções passam a predominar em sua produção. Esse não foi um fato isolado; de acordo com SEVERIANO (2008), a música instrumental que predominou nas primeiras gravações realizadas no Brasil (polcas, valsas, choros, etc.) foi progressivamente perdendo seu espaço na indústria fonográfica em função do sucesso de público alcançado pelas canções.

Nos arranjos das gravações selecionadas para este estudo é recorrente a presença da melodia principal executada pela sanfona nas introduções e nos interlúdios. Inclusive, é plausivel supor que a maioria das composições de Luiz Gonzaga tenha origem instrumental, vindo a ser letrada posteriormente por seus parceiros. 0 Baião na Garoa, por exemplo, foi gravado primeiramente como música instrumental em 1952. No mesmo ano, a música é regravada com letra, e passa a ser registrada com autoria de Luiz Gonzaga e Hervê Cordovil ${ }^{5}$. Dentre outros autores que fizeram parceria com o sanfoneiro, destacam-se Humberto Teixeira e Zé Dantas ${ }^{6}$.

Dessa forma, saindo do meio instrumental para o campo das canções, Luiz Gonzaga alcança maior popularidade e dá início a um processo de estilização do baião no meio musical urbano ${ }^{7}$. É a partir do momento em que foi gravado por Gonzaga no Rio de Janeiro no final da década de 1940, recebendo um tratamento específico de arranjo, letras, forma e instrumentação, que o baião ganha a formatação que marcou a sua especificidade dentro da história da música popular brasileira. Foi a partir dessa formatação, condicionada, sobretudo por necessidades dos setores da indústria fonográfica e do rádio, que 0 baião tornou-se uma referência para a produção musical posterior que visava remeter à música nordestina.

\footnotetext{
De fato, entre o final da década de 40 e meados dos anos 50, quando o baião apareceu nos meios musicais do Rio de Janeiro, a música nordestina dominou as execuções musicais no Brasil, conquistando compositores e intérpretes, às vezes sem nenhuma vinculação anterior com aquela região (FERRETTI, 1988, p.45).
}

Partindo de gravações realizadas entre as décadas de 1940 e 1950 nos debruçamos sobre o momento em que Gonzaga atua como figura principal na estilização do baião, e o consolida dentro do circuito rádio/disco ${ }^{8}$. Por meio de transcrições comentadas de trechos de composições desse período, busca-se ilustrar os elementos técnico-musicais que apresentam maior recorrência no repertório do músico, salientando que, na experiência musical, tais elementos ocorrem ao mesmo tempo e, na maioria das vezes, têm uma ligação muito forte entre si. É preciso levar em conta que a combinação dos elementos é que caracteriza aquilo que parte do público reconhece e aceita como "gênero musical", por exemplo: um contorno melódico específico, construído sobre determinada figura rítmica, executado com uma articulação peculiar e revestido por uma timbragem recorrente na prática musical em questão. Lembrando ainda que há muito mais do que elementos técnicos envolvidos nesse processo. Existe toda uma carga simbólica e cultural mobilizada pelos agentes envolvidos no fazer musical. Fatores extramusicais também contribuíram para caracterizar o baião "gonzagueano", e alavancaram sua repercussão no meio musical. Trabalhos como FERRETII (1988) e RAMALHO (1997) discorrem sobre o contexto político e sociocultural no qual o baião se desenvolveu, e também abordam outros aspectos, tais como o forte apelo à dança, as letras inspiradas em costumes, mitos, paisagens e personagens do nordeste, sua relação com os imigrantes nordestinos que habitavam a região sudeste e a construção de um personagem, portando a vestimenta que fazia alusão à figura de Lampião e aos vaqueiros do nordeste.

0 repertório usado como referência neste estudo é formado basicamente por canções que combinam estrofes e refrões cantados com introduções e interlúdios instrumentais. Todavia, trata-se de um repertório de canções que tem sido bastante utilizado para a elaboração de arranjos no formato instrumental. A composição Asa Branca de Luiz Gonzaga/Humberto Teixeira, por exemplo, recebeu várias gravações instrumentais onde técnicas de desenvolvimento do material melódico e de rearmonização são empregadas de forma abundante. Dentro dessa abordagem, podemos citar o arranjo "experimental" de Hermeto Pascoal no álbum A música livre de Hermeto Pascoal (Sinter) Phonogram, 1973), a versão jazzística feita pela pianista Eliane Elias em duo com Herbie Hancock, gravada no álbum Eliane Elias - solos and duets with Herbie Hancock (Blue Note, 1995), e o Concerto sinfônico para Asa Branca de Sivuca, uma versão orquestral gravada pelo músico com a Orquestra Sinfônica do Recife, sob regência do maestro Osman Gioia no álbum Sivuca Sinfônico (Biscoito fino, 2004).

\section{Combinações de elementos musicais que compõem o baião}

As considerações que serão traçadas a seguir têm como referência uma lista de quinze composições. A execução e apreciação musical das composições dessa lista possibilitam uma primeira aproximação do que ficou cristalizado como formato "clássico" do baião. Contudo, tais composições não são a única fonte para o estudo do material musical recorrente. Como o repertório do baião é bastante amplo, na medida do possível, outras peças serão comentadas ao longo do texto.

1. Baião ${ }^{9}$ de Luiz Gonzaga/Humberto Teixeira (1946)

2. Asa Branca ${ }^{10}$ de Luiz Gonzaga/Humberto Teixeira (1947)

3. Juazeiro de Luiz Gonzaga/Humberto Teixeira (1949)

4. Qui nem jiló de Luiz Gonzaga/Humberto Teixeira (1950)

5. A dança da moda de Luiz Gonzaga/Zé Dantas (1950)

6. Dezessete légua e meia - Humberto Teixeira/Carlos Barroso (1950)

7. No Ceará não tem disso não de Guio de Morais (1950)

8. Vem morena de Luiz Gonzaga/Zé Dantas (1950) 
9. Sabiá de Luiz Gonzaga/Zé Dantas (1951)

10. Baião da Penha de Guio de Morais/David Nasser (1951)

11. Paraiba de Luiz Gonzaga/Humberto Teixeira (1952)

12. Baião da Garôa de Luiz Gonzaga/Hervê Cordovil (1952)

13. Abc do sertão de Luiz Gonzaga/Zé Dantas (1953)

14. Algodão de Luiz Gonzaga/Zé Dantas (1953)

15. Vozes da seca de Luiz Gonzaga/Zé Dantas (1953)

A "levada" (condução rítmica) empregada em tais gravações é executada principalmente com zabumba e triângulo. "O ritmo, vindo das danças animadas do sertão, ganhou uma nova configuração com a introdução da zabumba, triângulo e acordeom, que se tornaram o conjunto típico, ao invés do original (viola, tamborim, botijão e rabeca) "11" (RAMALH0, 1997, p.92). Por vezes, encontramos nas gravações outros instrumentos de percussão como cowbell, agogô, ganzá e pandeiro. No entanto, apesar de tais instrumentos acrescentarem variedade ao aspecto timbrístico, do ponto de vista rítmico eles apenas reforçam os acentos realizados no triângulo e na zabumba. No Ex.1, a pauta superior corresponde ao triângulo e a pauta inferior corresponde à zabumba.

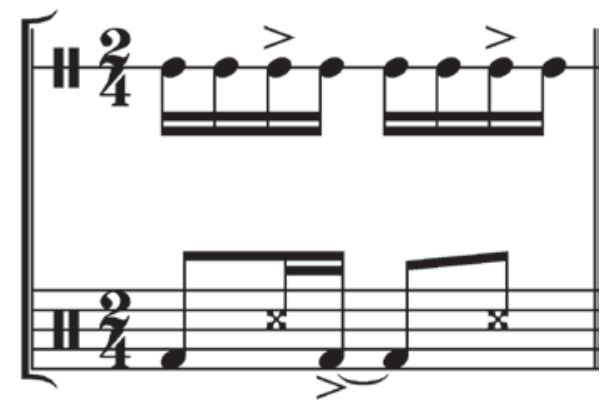

Ex.1 - "Levada" de baião executada por zabumba e triângulo.

0 triângulo mantém a subdivisão de semicolcheias acentuando os contratempos. Tal é acento, que é realizado pela mão esquerda, proporciona mudança de timbre. Temos um som aberto quando o acento ocorre. A zabumba, por sua vez, marca a pulsação através de acentos graves. 0 zabumbeiro também executa contratempos com o uso de uma baqueta de bambu que tem o nome de "bacalhau". É preciso deixar claro que o Ex.1 ilustra apenas a condução rítmica mais elementar, visto que há um grande número de variações dessa "levada" nas gravações. 0 zabumbeiro realiza frases utilizando os graves e diferentes acentuações com o "bacalhau" ${ }^{12}$.

É válido notar que a primeira gravação feita por Luiz Gonzaga da música Baião de Luiz Gonzaga/Humberto Teixeira, apresenta uma pequena diferença na execução da figura rítmica do acompanhamento. Observa-se nesta gravação a ausência da ligadura de extensão na execução da "levada". Ao invés da "levada" mostrada no Ex.2, ouvimos a condução da zabumba, mostrada no Ex.3.

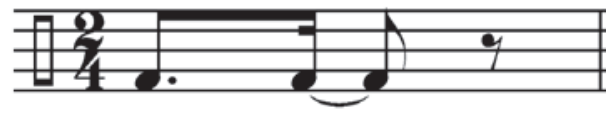

Ex.2 - Figura rítmica que se tornou referência da "levada" do baião.

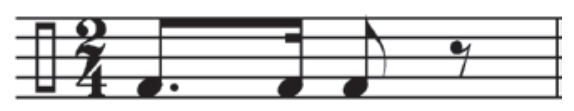

Ex.3 - Figura rítmica encontrada na gravação de Baião de 1949.

Entretanto, na gravação da música Juazeiro ${ }^{13}$ de Luiz Gonzaga/Humberto Teixeira, realizada no mesmo ano de 1949, já temos a presença da ligadura. Escutando as gravações posteriores, é possivel perceber que esta maneira de acompanhar tornou-se a forma padrão. Eventualmente a figura rítmica sem a ligadura aparece nos arranjos de alguns baiões, como por exemplo, em Dança da moda de Luiz Gonzaga/Zé Dantas e na introdução de Paraiba de Luiz Gonzaga/Humberto Teixeira (Ex.20), onde a zabumba e o violão realizam a mesma figura rítmica por alguns compassos e depois mudam para 0 acompanhamento padrão.

Instrumentos relacionados com o repertório do choro e do samba, tais como o cavaquinho e o violão 7 cordas, provenientes do grupo "regional" ${ }^{14}$, foram utilizados nas gravações de Gonzaga. É interessante notar o conflito inicial que ocorreu quando músicos com experiência no choro/samba começaram a gravar baiões. Na gravação de 1950 da composição Qui nem jiló de Luiz Gonzaga/Humberto Teixeira, ouve-se o violão 7 cordas executando semínimas, enquanto a zabumba realiza a "levada" •. $\cdot$. , ocasionando assim um pequeno desencontro nos graves. Em gravações posteriores percebemos que o violão de 7 passa a executar a mesma figura da zabumba. Parece que foi necessário um período de adaptação para os músicos cariocas assimilarem a "levada" do baião.

Tais comentários revelam um pouco do processo de estilização, evidenciando que o baião não chegou pronto, como um produto acabado, mas sim, que foi estruturando-se em meio às seções de gravações.

Tomando a "levada" padrão como um elemento fixo, que sustenta e interage com os elementos variáveis, vamos adentrar nas combinações de elementos musicais presentes no repertório do baião. Para tanto, comecemos como uma melodia construída predominantemente por colcheias. As colcheias quando executadas sobre a "levada" formam 0 contraponto de maior recorrência no baião. 
No Ex.4, nota-se a predominância das colcheias na construção da melodia (pauta superior) contra a figura rítmica, realizada na região grave da zabumba, que apresenta maior recorrência no acompanhamento (pauta inferior). Para um instrumentista que está tendo os primeiros contatos com o baião, a execução desses dois elementos já fornece uma boa ideia da relação mais elementar entre melodia e acompanhamento no repertório de Luiz Gonzaga.

Outro elemento recursivo, que também pode ser conferido em No Ceará não tem disso não, é a utilização de traços modais. Encontramos certos contornos melódicos com esse caráter, combinados com cadências tonais, como em Baião de Luiz Gonzaga/Humberto Teixeira (Ex.8), Juazeiro de Gonzaga/Humberto Teixeira
(Ex.11), Algodão de Luiz Gonzaga/Zé Dantas (Ex.10), Baião da garoa de Luiz Gonzaga/Hervê Cordovil (Ex.15), Baião da penha de Guio de Morais/David Nasser, Vozes da seca de Luiz Gonzaga/Zé Dantas e Vem morena de Luiz Gonzaga/Zé Dantas (Ex.5).

A introdução de "Vem Morena" apresenta basicamente a melodia da seção A no formato instrumental. Temos aqui quatro frases de oito compassos. As duas primeiras frases são harmonizadas pelos acordes Im7 e IV7 que apresentam a sonoridade do modo dórico. Como observou TINÉ (2008, p.96-99), as duas últimas frases, que são harmonizadas com uma cadência tonal Im7-V7-Im7, também poderiam ser harmonizadas com os acordes de Fm7 e Bb7, mantendo o ritmo harmônico de um acorde por compasso. A cadência tonal não se faz imprescindível, pois a sensível

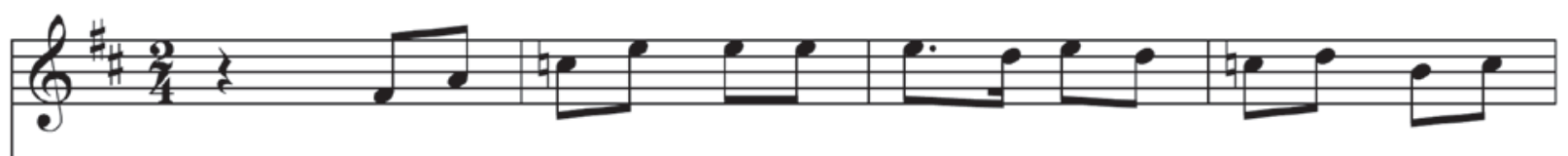

D7
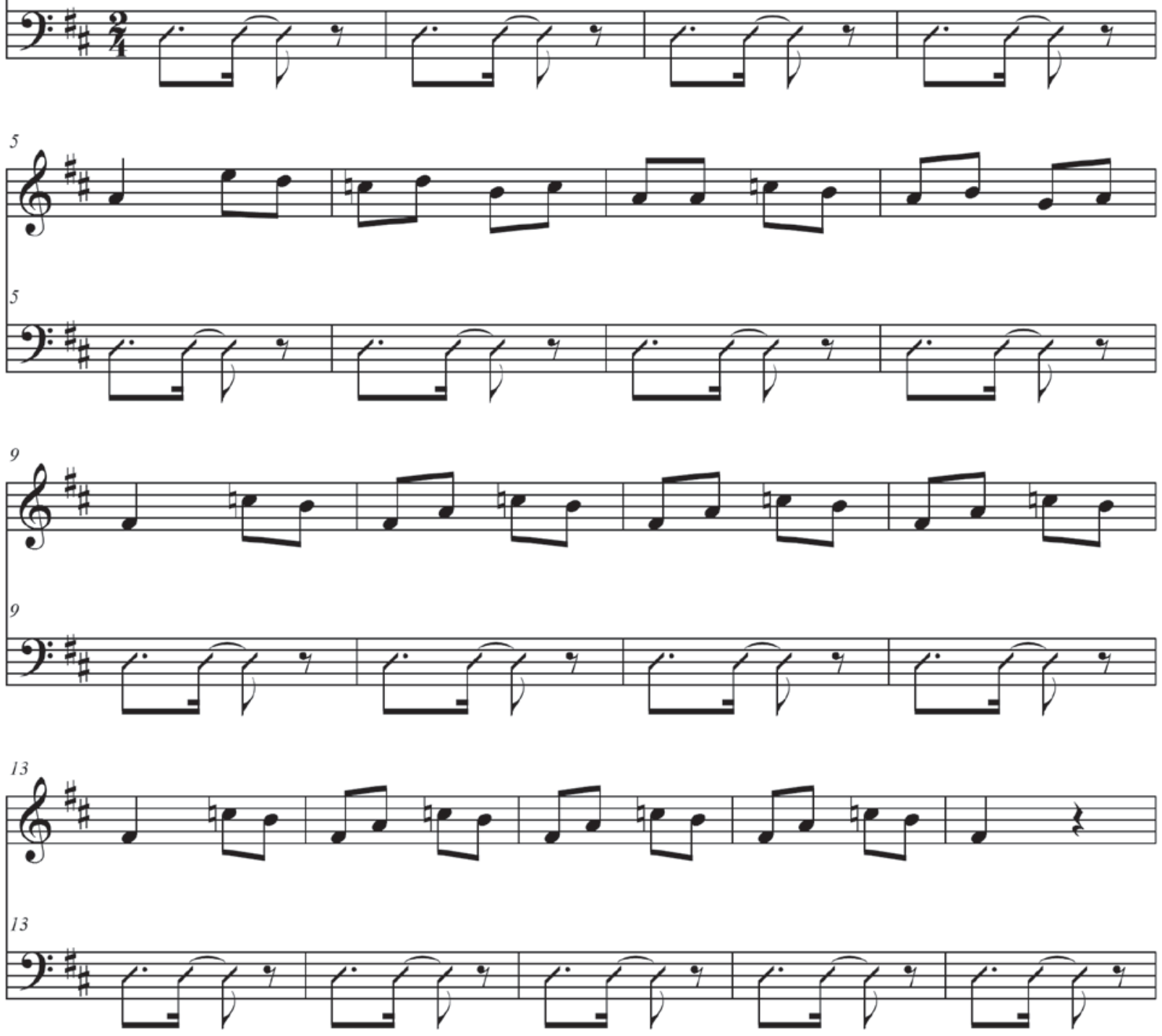

Ex.4 - Trecho da seção A de No Ceará não tem disso não de Guio de Moraes. 
$\mathrm{Fm} 7$
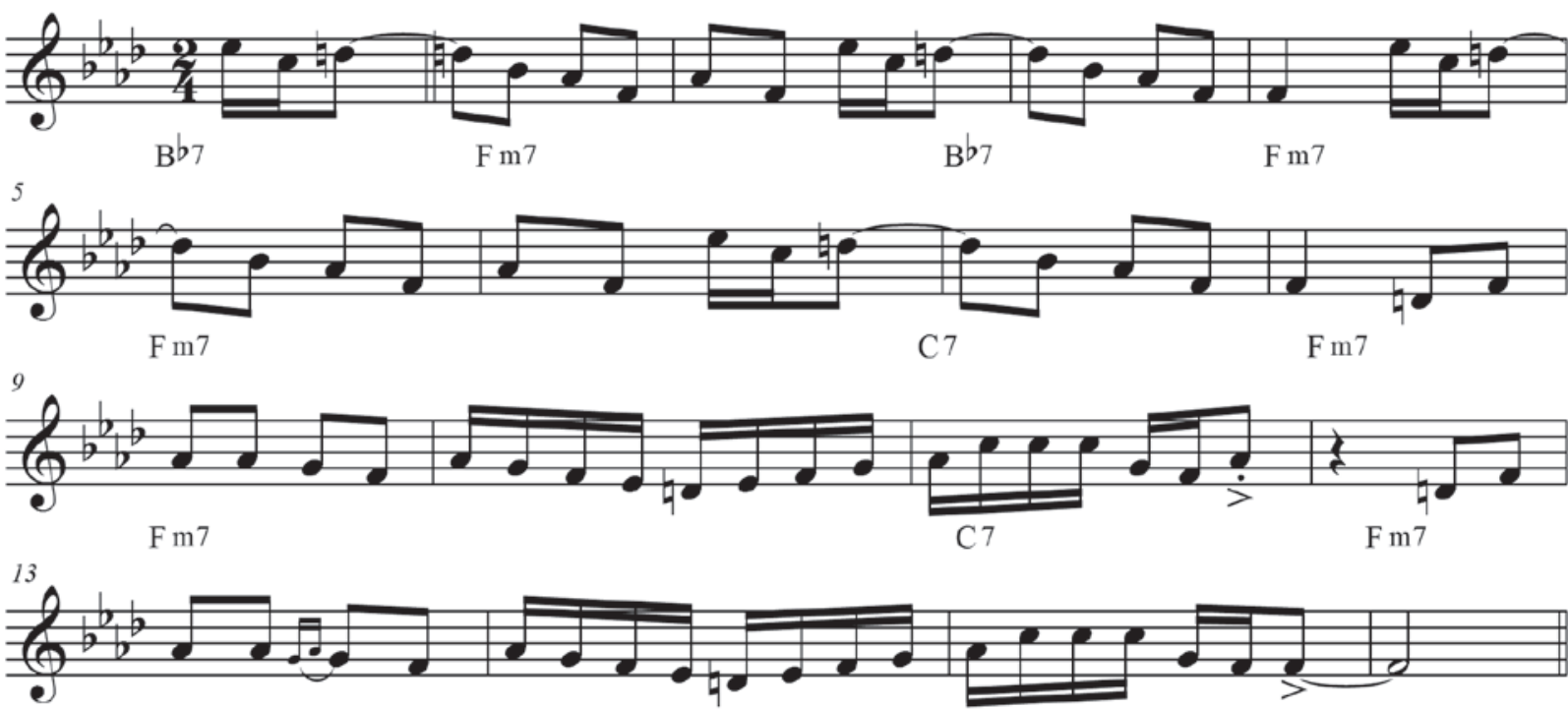

Ex.5 - Introdução presente na gravação de 1950 de Vem morena de Luiz Gonzaga/Zé Dantas.
G

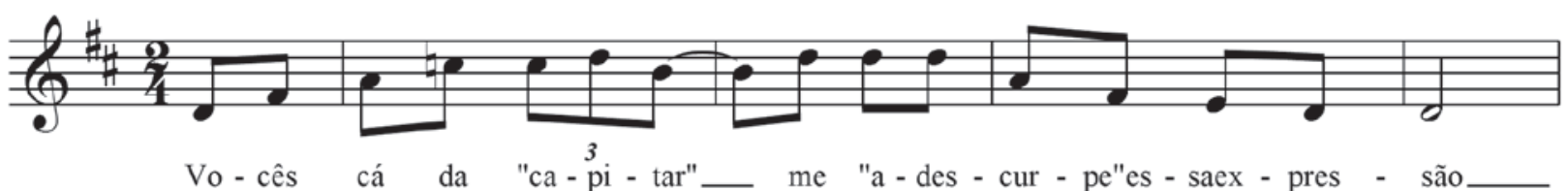

Ex.6 - Letra e melodia do trecho final da seção A de No Ceará não tem disso não de Guio de Moraes.

da tonalidade não aparece na melodia. Contudo, como os últimos dezesseis compassos representam uma seção contrastante, é possível que a cadência tonal tenha sido utilizada para acentuar tal embate ${ }^{15}$.

Quando o baião foi estilizado e lançado no mercado havia todo um repertório de caráter exclusivamente tonal que predominava nos meios de comunicação. Nota-se que Gonzaga se apropriou de elementos musicais presentes no repertório que ele precisou aprender para poder iniciar sua carreira como solista.

\footnotetext{
0 primeiro estágio [da carreira de Luiz Gonzaga] - 1941-46 - o revela como um intérprete e compositor do repertório popular do Rio de Janeiro, desde Ernesto Nazareth até suas próprias criações de mazurcas, choros, valsas, polcas e sambas adaptados para o acordeom. Ao mesmo tempo, ele introduziu várias músicas que não pertenciam a tais gêneros, as quais ele trouxe do sertão - como o xote, xaxado, miudinho, seridó e calango - uma variedade de danças muito populares em sambas e forrós ${ }^{16}$ (RAMALHO, 1997, p.108-109)
}

Essa relação modal/tonal presente na música de Luiz Gonzaga pode ser interpretada dentro da ideia de "fricção" proposta por PIEDADE. "[...] Uma situação na qual as musicalidades dialogam mas não se misturam: as fronteiras musical-simbólicas não são atravessadas, mas são objetos de uma manipulação que reafirma as diferenças" (PIEDADE, 2005, p.200). Gonzaga trazia consigo a sonoridade modal, absorvida pela sua vivência e atuação profissional como sanfoneiro em sua terra natal (Exu-PE), e esta sonoridade foi "friccionada" com as referências tonais que o músico foi adquirindo durante sua atuação no mercado carioca.

Vê-se um caso ilustrativo envolvendo melodia e letra do baião No Ceará não tem disso não de Guio de Morais. A seção $A$ apresenta um contorno melódico elaborado sobre o modo mixolídio (Ex.4) com a seguinte letra cantada na primeira pessoa: "tenho visto tanta coisa nesse mundo de meu Deus / coisas que "prum" cearense não existe a "expricação", "quarquer" pinguinho de chuva fazer uma inundação / moça se vestir de cobra e dizer que é distração." Porém, quando são cantados os versos que se referem às pessoas que vivem na capital 17: "vocês cá da "capitar" me "adescurpe" essa expressão", a cadência tonal (IV V7 I) é inserida como uma espécie de alusão ao tipo de música que representa a tal "capitar" (Ex.6).

Dando sequência à amostragem das combinações entre os elementos, temos uma composição onde predominam grupos de quatro semicolcheias juntamente com algumas figuras rítmicas que derivam dessa subdivisão. 
B7

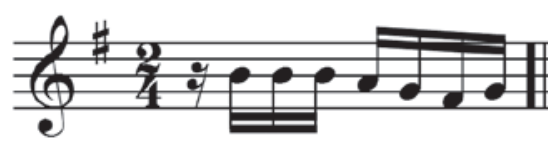

B 7

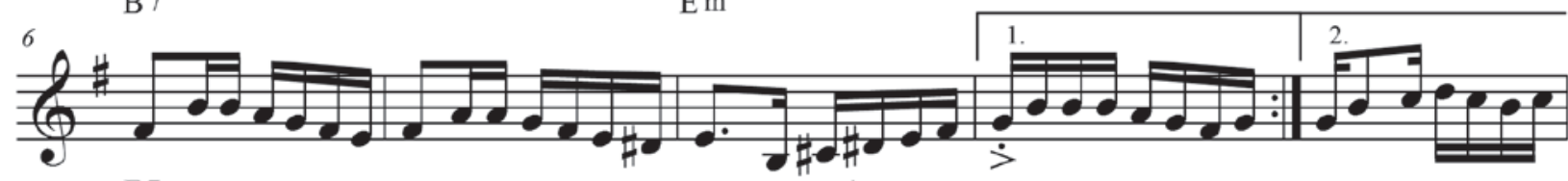

E7

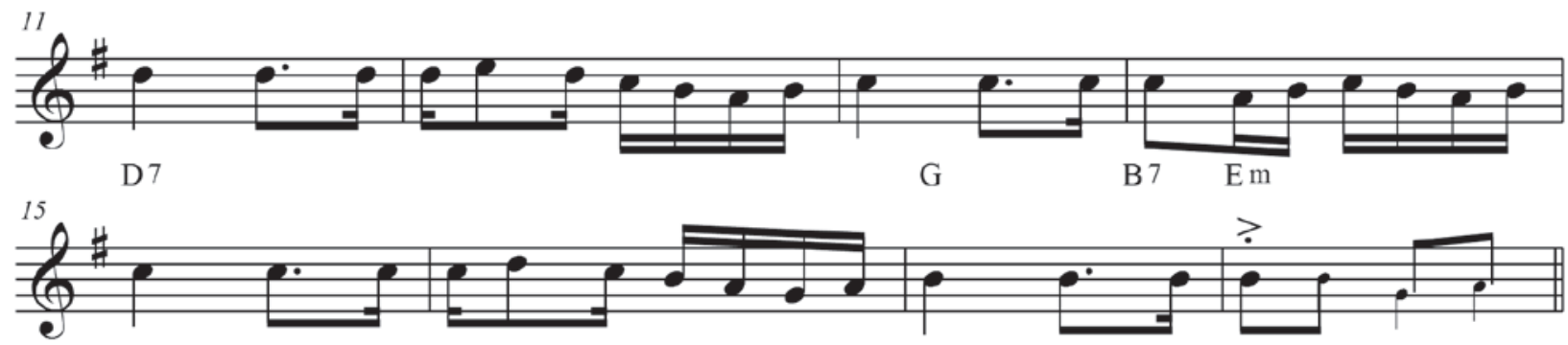

Em

Ex.7 - Trecho de Sabiá de Luiz Gonzaga/Zé Dantas.

Sabiá nos mostra também que a utilização de elementos modais não foi imprescindível na elaboração do baião. Dentre outras composições estritamente tonais, pode-se citar Abc do sertão de Luiz Gonzaga/Zé Dantas (Ex.17), A dança da moda de Luiz Gonzaga/Zé Dantas, Xanduzinha de Luiz Gonzaga/Humberto Teixeira, Macapá de Luiz Gonzaga/Humberto Teixeira, etc. Tais fatos demonstram que a música de Luiz Gonzaga transita entre o modal e o tonal, representando um dos casos de "dessistema" (FREITAS, 2010) presentes nas práticas populares.

\footnotetext{
[...] Nos deparamos com construtos musicais que seguem aquele outro viés - aquele dos fazeres inorganizados, das composições desconformes, das incoesões, das adesões incompletas, desobrigadas, desobedientes, anti-absolutas, irônicas, niilistas, modernosas, dos conjugados ecléticos e imperfeitos, dos vestígios amontoados, dos restos avariados, dos desvios de padrão que se tornam regras constantes, etc. -, e mesmo assim, mesmo quando podemos perceber que estamos lidando com algum dessistema [...], não conseguimos reagir declarando formalmente que não se trata de encaixar as coisas em um ou outro sistema (modal ou tonal), e sim de avaliar um construto que não se acomoda satisfatoriamente em sistema algum (FREITAS, 2010, p.327).
}

Ao pesquisar as combinações de figuras rítmicas presentes no repertório do baião, é possível perceber alguns padrões de maior destaque. Um dos mais recorrentes é formado por quatro colcheias, sendo a última colcheia ligada com o primeiro tempo do próximo compasso. 0 Ex.8 representa, de forma aproximada, a melodia de Baião, conforme interpretada na gravação de 1949 por Luiz Gonzaga. Vemos aqui o emprego do padrão em questão ao longo da melodia. Pode-se notar novamente a presença de algumas subdivisões em semicolcheia, porém em menor número em relação às colcheias.
Vê-se uma espécie de antecipação que por vezes gera uma relação dissonância/consonância. Tal relação pode ser observada, por exemplo, na passagem do c.13 para o c.14 do Ex.8. Nesse momento a nota Mi bemol é atacada como dissonância de décima primeira em relação ao acorde de $\mathrm{Bb} 7{ }^{18}$, e resolve como fundamental do acorde de Eb7.

Na introdução, presente na mesma gravação de 1949 (Ex.9), há duas combinações de figuras rítmicas com duração de dois compassos cada, que são formadas por "garfinhos" (semicolcheia-colcheia-semicolcheia) com uma semínima, colcheias e ligaduras de extensão.

A pausa de semicolcheia no início de frases envolvendo esse tipo de combinação é um elemento a ser levado em conta na composição do baião. Frases começando na segunda colcheia do primeiro tempo geram impulso e proporcionam sensação de movimento.

No Ex.10 temos mais um trecho que demonstra um pouco mais das possiveis combinações entre "garfinhos", colcheias e semínimas com contornos melódicos realizados sobre 0 modo mixolídio. Nos dois últimos compassos observa-se novamente o padrão formado por quatro colcheias com ligadura de extensão na última colcheia.

\section{Elementos da cantoria estilizados no baião}

A presença de traços modais no baião faz alusão a determinadas manifestações culturais nordestinas (as bandas de pífanos, violeiros, cantadores, aboios e novenas), denominadas como "folclóricas" ou classificadas como material étnico. Em sua tese de doutorado, TINÉ (2008) 


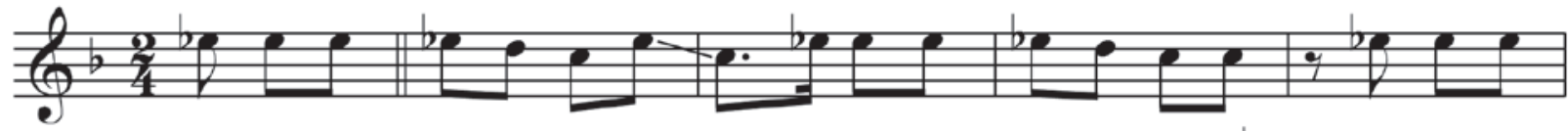

$\mathrm{B}^{\mathrm{b}} 7$
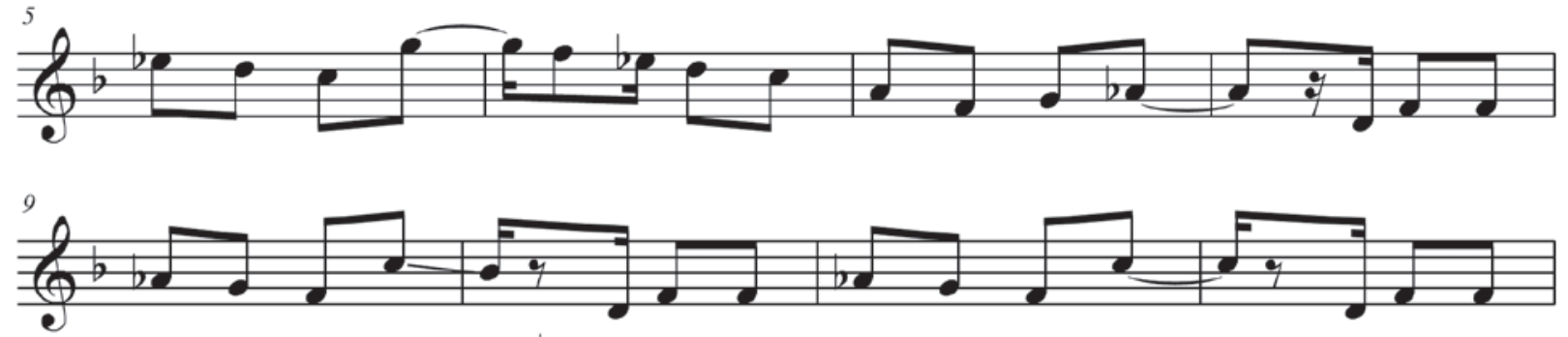

Eb7

C 7

F 7

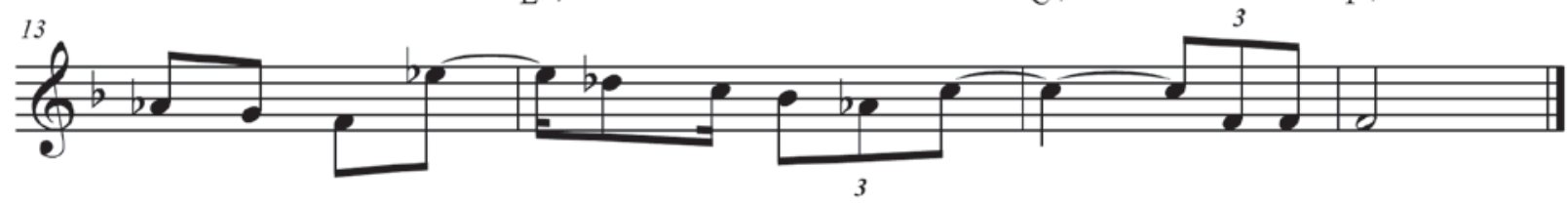

Ex.8 - Seção A de Baião de Luiz Gonzaga/Humberto Teixeira.

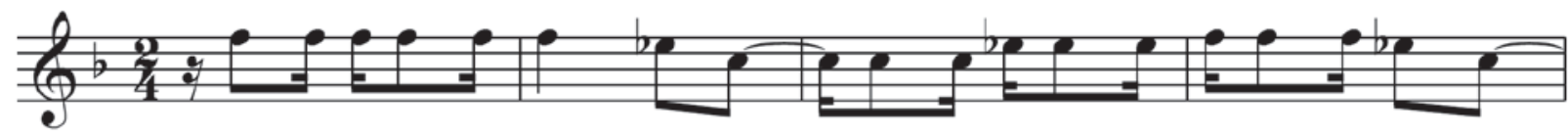

Ex.9 - Trecho da introdução da gravação de 1949 de Baião de Luiz Gonzaga/Humberto Teixeira.

D 7
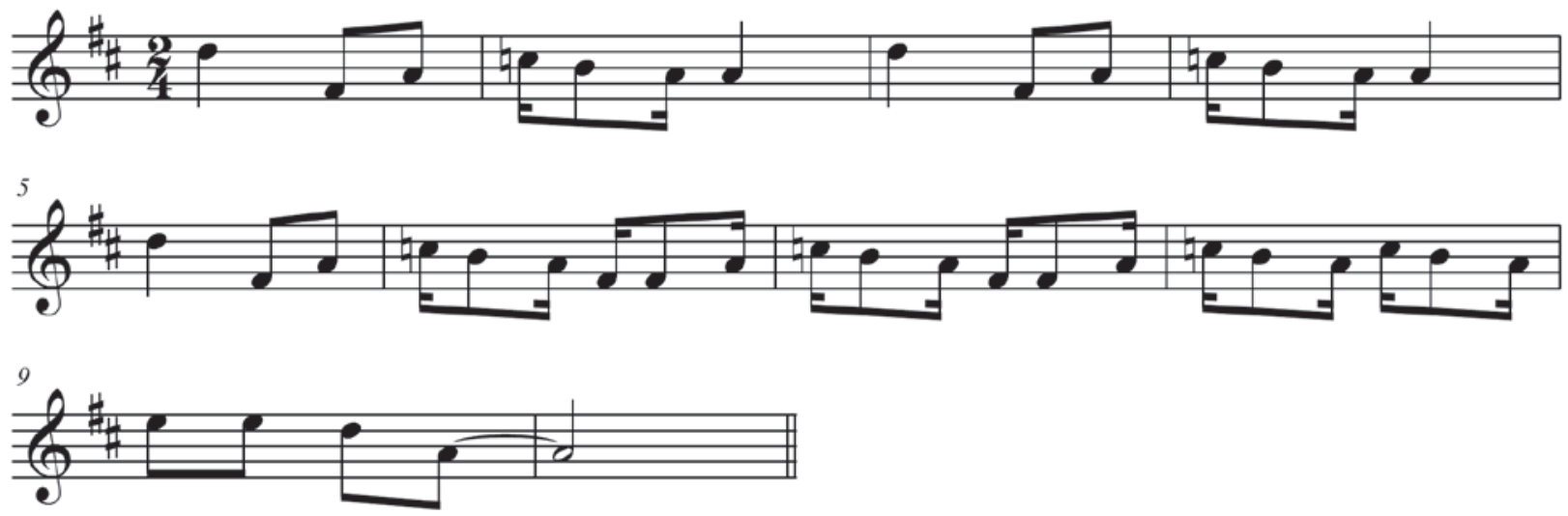

Ex.10 - Trecho da seção A da música Algodão de Luiz Gonzaga/Zé Dantas. 
fornece análises de melodias de tradição oral colhidas no nordeste. Com base em tal estudo, percebe-se que grande parte dos elementos recorrentes no baião pode ser encontrada na prática da cantoria ${ }^{19}$. É possível sintetizar tais elementos através do seguinte levantamento:

1. Utilização dos modos mixolídio e dórico;

2. Começo das frases em anacruse ou sem o primeiro tempo (compasso acéfalo);

3. Arpejo em posição fundamental seguido da sétima menor do modo como ponto de apoio;

4. Ênfase dada à sétima e uso da sexta e quinta para dar continuidade à melodia;

5. Padrões em intervalos de terça ou sextas;

6. Uso de notas repetidas na elaboração melódica;

\subsection{Utilização dos modos mixolídio e dórico}

Os Exs.11 e 12 mostram passagens que utilizam os dois modos recorrentes no baião: o mixolídio e o dórico ${ }^{20}$

Vejamos o caso da composição Baião, que se tornou emblemática. Quando se busca evocar o baião, o motivo inicial dessa composição é uma das primeiras referências que os músicos utilizam ${ }^{21}$. Ao ser indagado sobre como faria para improvisar em uma música "moderna" utilizando elementos do baião "tradicional", o saxofonista Mané Silveira ${ }^{22}$ respondeu: "eu faria primeiro aquela: (solfeja as primeiras notas de "Baião")". Em consonância com os comentários de TINÉ (2008, p.92), observa-se que a melodia de "Baião" que ficou mais conhecida é

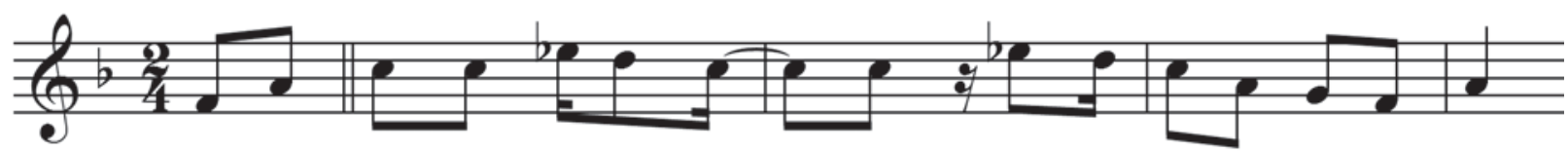

Ex.11 - Modo mixolídio - trecho da seção A de Juazeiro de Luiz Gonzaga/Humberto Teixeira.

$\mathrm{F} \mathrm{m} 7$

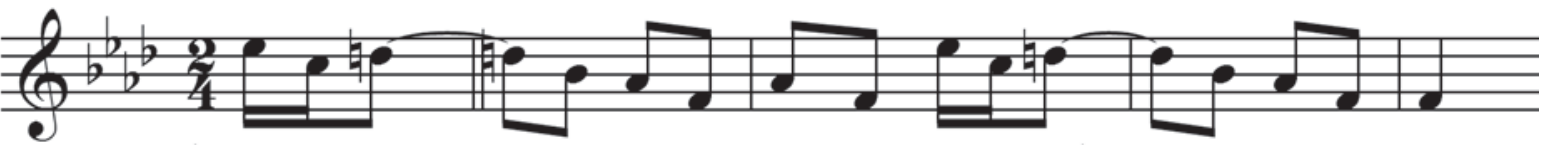

Ex.12 - Modo dórico - trecho da seção A de Vem Morena - Luiz Gonzaga/Zé Dantas.

F 7
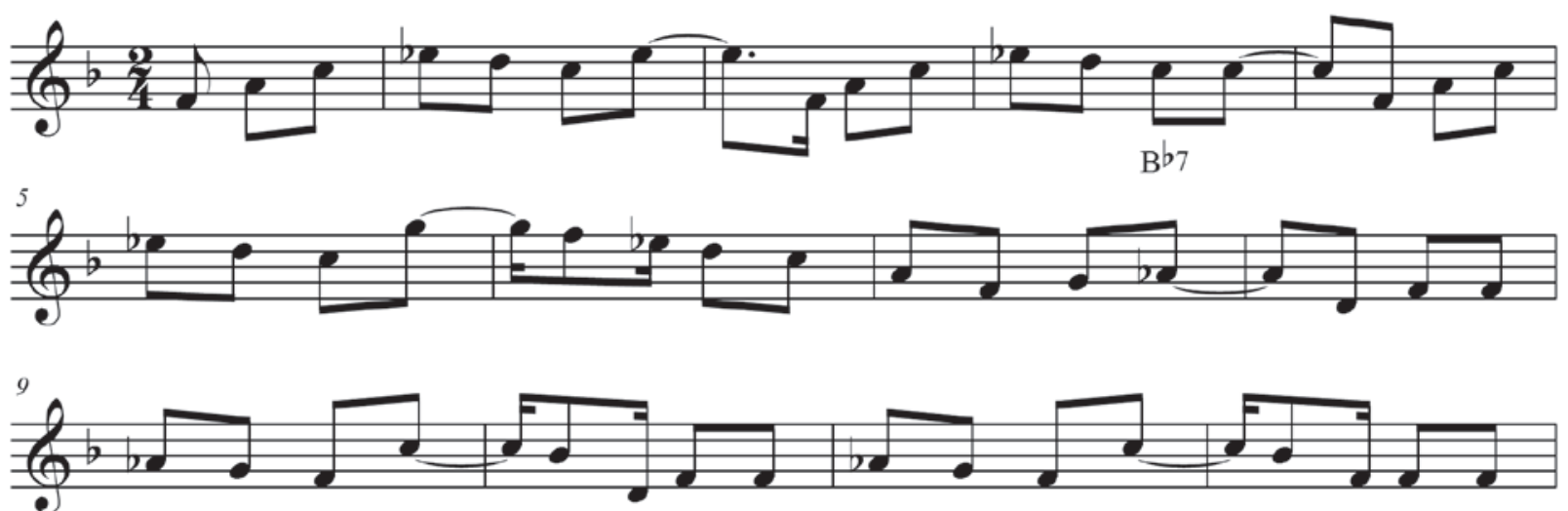

Eb7

C7

F7

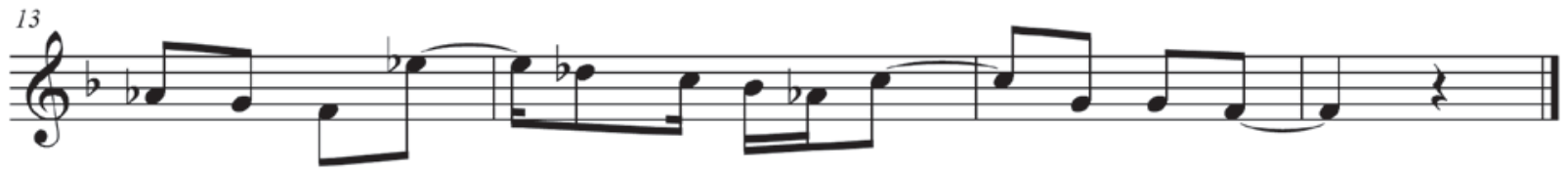

Ex.13 - "Versão instrumental" da seção A de Baião de Luiz Gonzaga/Humberto Teixeira. 


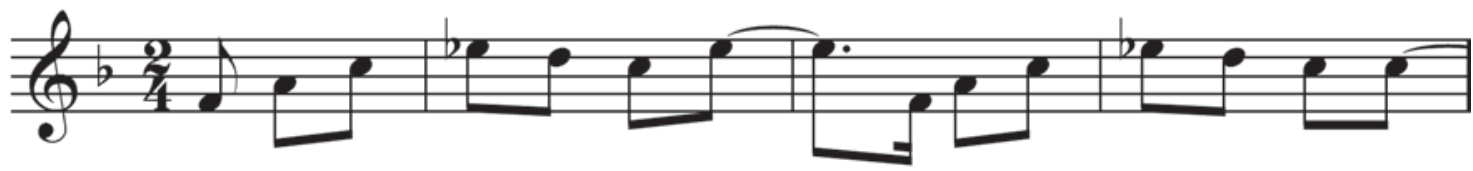

Ex.14 - Primeiras notas da "versão instrumental" de Baião de Luiz Gonzaga/Humberto Teixeira.

$\mathrm{Gm}$

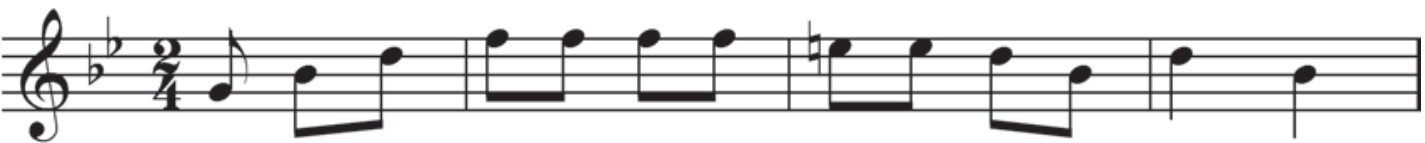

Ex.15 - Primeiras notas do terceiro verso de Baião da Garoa de Luís Gonzaga/Hervé Cordovil

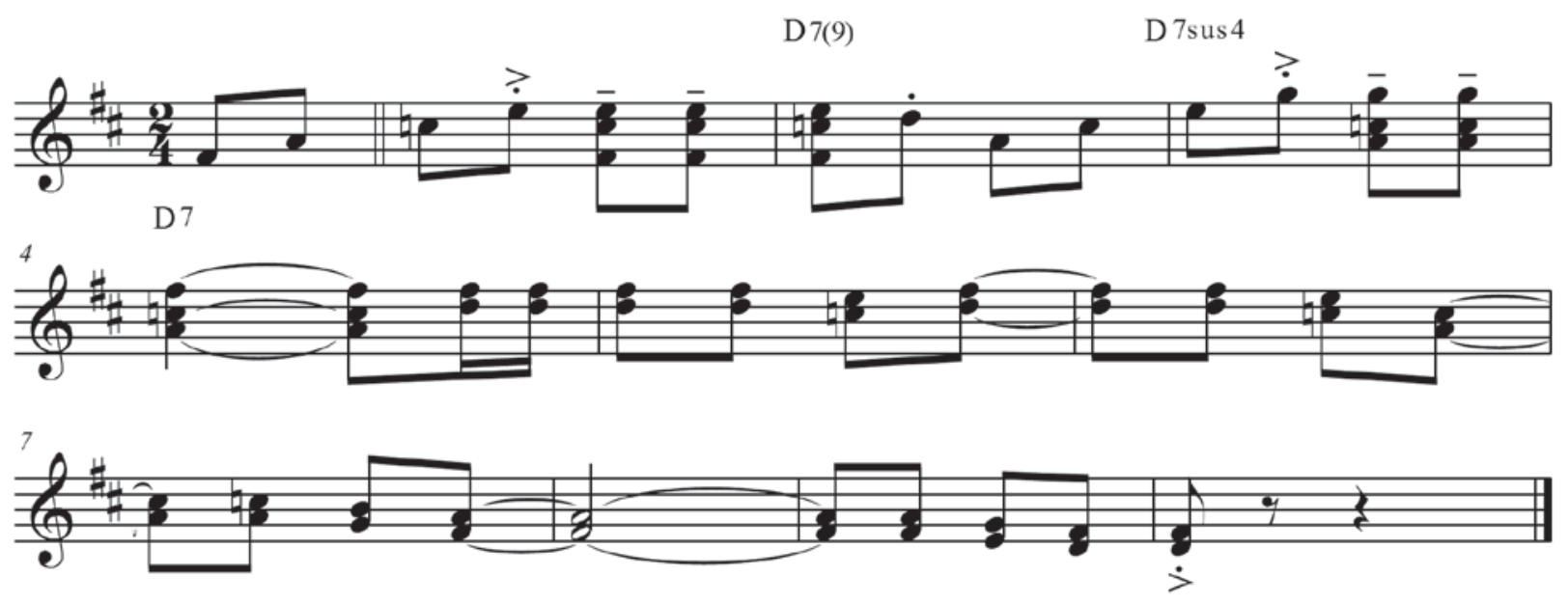

Ex.16 - Introdução presente na gravação de 1950 de No Ceará não tem disso não de Guio de Moraes.

um misto da linha melódica cantada por Luiz Gonzaga (Ex.8) e a parte instrumental executada pelo próprio à sanfona. Dessa forma, temos aproximadamente a "versão instrumental" mostrada no Ex. 13.

0 próprio Gonzaga citou a melodia de Baião na gravação de 1950 de Dezessete légua e meia de Humberto Teixeira/Carlos Barroso. Na letra da canção, o locutor fala que andou dezessete léguas e meia sem parar para ir a um forró dançar. Após chegar à festa ele faz o seguinte comentário: "quando Zé sanfoneiro gemeu no fole o baião", e então as primeiras frases de Baião são executadas à sanfona. Trata-se de um motivo que já foi bastante explorado. Contudo, apesar de ter se tornado um clichê, o motivo é importante na construção melódica do baião, sendo usado não apenas no modo mixolídio, mas também no modo dórico, como veremos a seguir.

\subsection{Compasso acéfalo, arpejo ascendente e sétima menor como ponto de apoio}

Observando as primeiras notas da "versão instrumental" de Baião de Luiz Gonzaga/Humberto Teixeira, e da melodia de Baião da garoa de Luiz Gonzaga/Hervé Cordovil, percebe-se que, exceto pelas terças maior e menor que diferenciam os modos mixolídio e dórico, elas têm uma construção semelhante e possuem elementos que remetem à cantoria. Nota-se o compasso acéfalo, o arpejo ascendente enfatizando a sétima menor, alcançada por salto, e o contorno melódico diatônico descendente, passando pela sexta e pela quinta dos modos.

Tais contornos melódicos podem ser explorados e desenvolvidos na confecção de um solo improvisado que almeje ser reconhecido como "idiomático" ${ }^{23} \mathrm{em}$ relação ao baião. 0 Ex.16 apresenta uma forma de variar esse fraseado. 
Nessa introdução, realizada por Luiz Gonzaga à sanfona, encontramos o arpejo inicial começando pela terça e não pela fundamental. Dessa forma, a nona passa a ser a nota enfatizada (c. 1 e 2) ao invés da sétima. Em seguida temos o mesmo arpejo realizado a partir da quinta, enfatizando a quarta como ponto de apoio e gerando um acorde com a quarta suspensa. Seguindo o mesmo padrão apresentado na introdução, pode-se realizar esse arpejo a partir do sétimo grau também.

\subsection{Padrões melódicos - terças/sextas e notas repetidas}

A realização de frases em intervalos de terças harmônicas ou mesmo em sextas, que são as terças invertidas e geram um resultado sonoro similar, constitui outro recurso que pode ser empregado para o desenvolvimento de um improviso "idiomático" relacionado ao baião. Ao executar o repertório escolhido para esta pesquisa pode-se constatar que, de modo geral, os contornos melódicos possibilitam a adição de terças harmônicas. Por vezes encontramos tais terças nos vocais presentes nas gravações.

0 Ex.17 ilustra mais um caso de uso das terças harmônicas na melodia.

Certos padrões realizados em terças melódicas, que são encontrados no repertório do baião, também podem ser úteis na construção de um arranjo que vislumbre apontar para o baião "gonzagueano". São padrões relativamente simples, porém, quando realizados com a subdivisão rítmica em colcheias e com certos recursos de articulação, se mostram efetivos para representar o baião. Encontramos tais padrões em músicas como No Ceará

A m

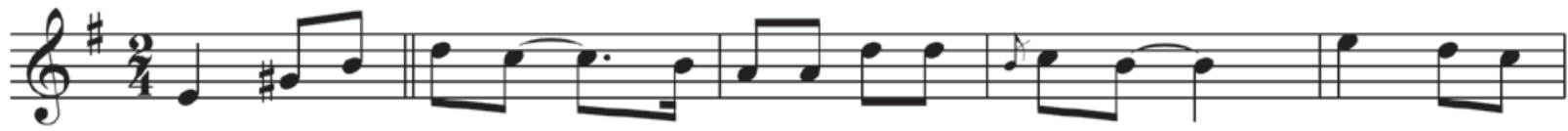

B 7

Em

B7

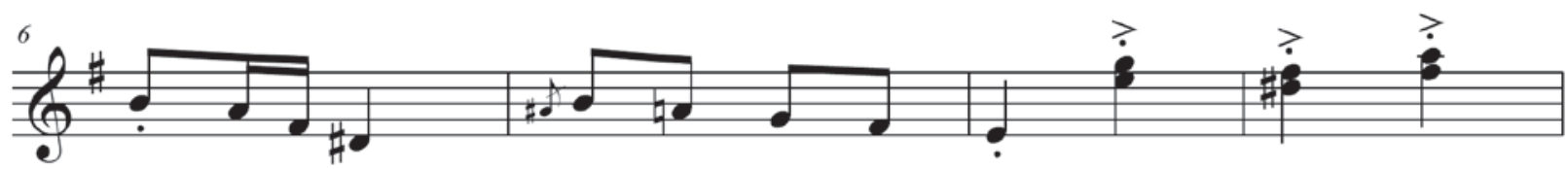

$\begin{array}{llll}\text { Em } & \text { B7 } & \text { Em } & \text { B7 }\end{array}$
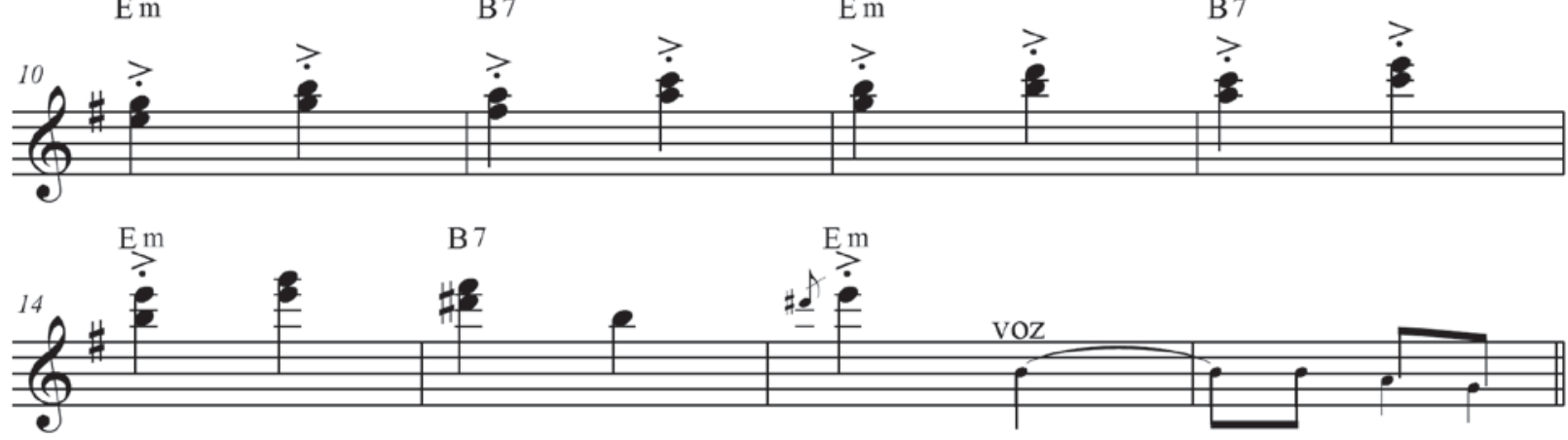

Ex.17 - Intervalos de terças harmônicas na introdução de $A B C$ do sertão de Luiz Gonzaga/Zé Dantas, presente na gravação de 1953.
$\mathrm{C} / \mathrm{E} \quad \mathrm{G}$
A m $\quad$ G
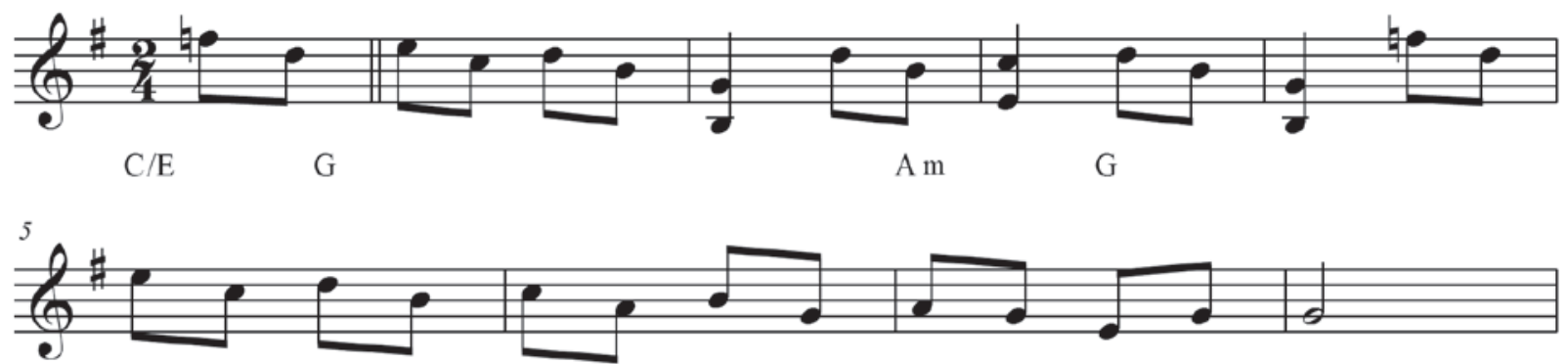

Ex.18 - Padrões de terças melódicas na introdução utilizada na gravação de 1952 de Asa branca de Luiz Gonzaga/Humberto Teixeira. 
não tem disso não (Ex.4), e na introdução da gravação de 1952 de Asa branca de Luiz Gonzaga/Humberto Teixeira, transcrita no Ex.18. Nota-se também a adição de intervalos harmônicos de sexta entre os c.2 e 5.

Outro procedimento recorrente na elaboração melódica do baião é a utilização de notas repetidas. É possivel verificar o uso desse recurso tanto sobre a subdivisão rítmica de semicolcheias (conferir Vem morena no Ex.5 e Sabiá no Ex.7), quanto na subdivisão de colcheias, como nas seções B de Baião, Baião da Garoa de Luiz Gonzaga/ Hervê Cordovil e Qui nem jiló (Ex.19).

\section{Utilização de recursos idiomáticos da sanfona}

Entre os c.2 e 5 da introdução inserida na gravação de 1952 de "Paraiba" - Luiz Gonzaga/Humberto Teixeira (Ex.20), nota-se um pequeno padrão utilizando intervalos de quartas. Gonzaga utiliza recursos idiomáticos da sanfona nessa introdução. Ele adiciona uma nota da melodia por vez, em duas oitavas simultâneas ${ }^{24}$, e sustenta todas as notas ao mesmo tempo, gerando assim um efeito timbrístico peculiar.

Outro caso é o uso do chamado "jogo de fole" para repetir a mesma nota em subdivisão de semicolcheia. Esse recurso pode ser encontrado no final da introdução de "Paraíba".
Segundo DIAS (2011), a utilização do fole dessa forma "percussiva" é advinda da prática da sanfona de 8 baixos, e foi adaptada por Gonzaga para a sanfona de 120 baixos ${ }^{25}$.

\begin{abstract}
Ao inserir elementos novos no cenário musical brasileiro, Luiz Gonzaga também inovou no acompanhamento para a sanfona e na técnica de execução do instrumento. [...] Adaptou para a sanfona de 120 baixos a técnica do jogo de fole da sanfona de 8 baixos da tradição nordestina, que conheceu ainda criança, filho que era do Mestre Januário, afamado tocador de fole de 8 baixos na região do Araripe pernambucano (DIAS, 2011, p.21).
\end{abstract}

A agilidade na execução de notas nos dois movimentos, abrindo e fechando a sanfona, exigiu o desenvolvimento de uma técnica mais contida na abertura do fole, promovendo um jogo de fole peculiar, técnica que Luiz Gonzaga aprendeu ainda menino, e traduziu para a sanfona de 120 baixos, cujo efeito sonoro ficou conhecido como o "resfolego" da sanfona. (DIAS, 2011, p.25)

\section{Detalhes de articulação: o sotaque do baião}

A interpretação de Luiz Gonzaga representa um possivel modelo a ser tomado como base para a compreensão de detalhes de articulação recorrentes no baião. A audição e emulação cuidadosa das inflexões presentes em sua forma de cantar consistem em atividades importantes para a absorção do acento encontrado no baião.

Como visto até agora, temos duas subdivisões rítmicas que se destacam no baião: colcheias e semicolcheias. Em relação à articulação das colcheias, observa-se

A 7

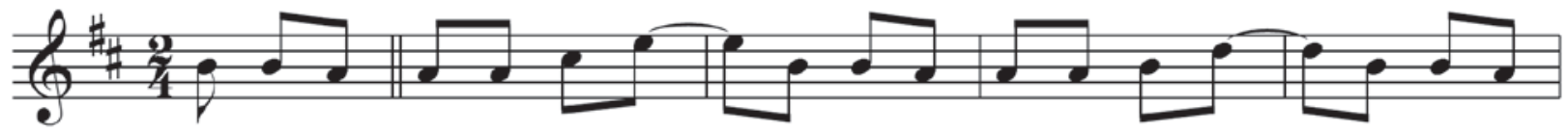

A 7

D 6

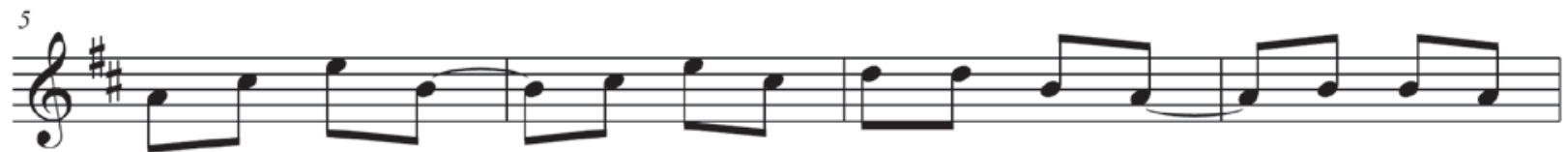

Ex.19 - Utilização de notas repetidas na seção B de Qui nem jiló de Luiz Gonzaga/Humberto Teixeira.

A

A 6
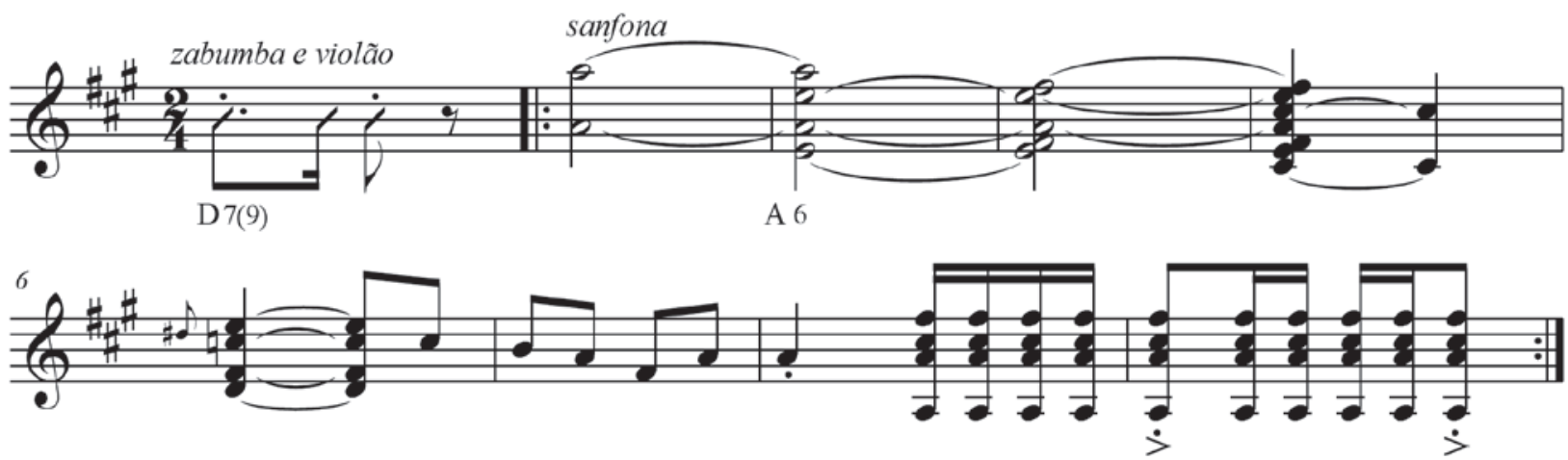

Ex.20 - Recursos idiomáticos da sanfona na introdução de Paraíba de Luiz Gonzaga/Humberto Teixeira. 
D7

G 6

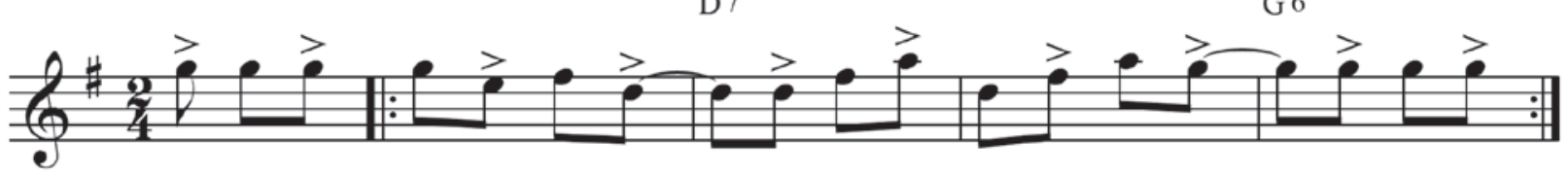

Ex.21 - Trecho final da gravação de 1950 de Dezessete légua e meia de Humberto Teixeira/Carlos Barroso.

que há uma leve acentuação nos contratempos. No final da música Dezessete légua e meia de Humberto Teixeira/Carlos Barroso, Gonzaga fica repetindo o trecho transcrito no Ex.21.

Observa-se aqui novamente a presença do padrão formado por quatro colcheias com ligadura de extensão na última colcheia. A combinação de tal padrão com a acentuação dos contratempos é representativa na articulação do baião. A título de ilustração, foram adicionados acentos nos contratempos do Ex.21. Porém, como mencionado, essa acentuação é bem sutil. É necessário ter cuidado com tal articulação a fim de evitar um resultado sonoro caricato.

A acentuação dos contratempos pode estar presente mesmo quando a subdivisão rítmica é realizada em semicolcheias. Nesse caso, pode-se usar a condução do triângulo como modelo.

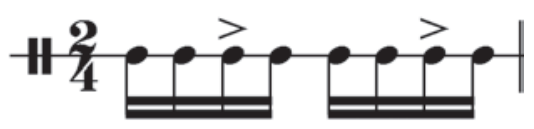

Ex.22 - Condução do triângulo com acentuação nos contratempos.

Como vimos anteriormente (Ex.1), esse acento está presente tanto no triângulo quanto no "bacalhau" da zabumba.

Vejamos agora outra opção de acentuação para as semicolcheias, tomando como base a "levada" da sanfona. No Ex.23, a pauta superior representa a sanfona e a pauta inferior mantém a condução mais elementar da zabumba.

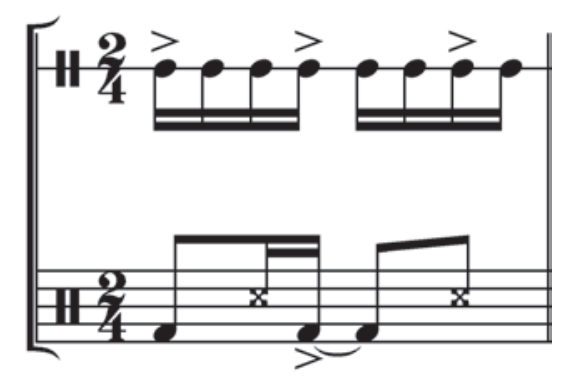

Ex.23 - Zabumba e sanfona - padrão 3+3+2 na "levada" da sanfona.

Aqui a sanfona executa as semicolcheias utilizando uma acentuação que combina tanto com a parte grave quanto com o "bacalhau" da zabumba. Tal acentuação gera o padrão $3+3+2$, que tem se mostrado recorrente em várias manifestações populares.
0 padrão rítmico $3+3+2$ [denominado por musicólogos cubanos como tresillo] pode ser encontrado hoje na música brasileira de tradição oral, por exemplo nas palmas que acompanham o sambade-roda baiano, o coco nordestino e o partido-alto carioca; e também nos gonguês dos maracatus pernambucanos, em vários tipos de toques para divindades afro-brasileiras e assim por diante (SANDRONI, 2001, p.28).

A arte final da articulação é dada pela inserção do vibrato. Impossivel transcrever o vibrato que se tornou representativo, para compreendê-lo é imprescindivel a audição cuidadosa da interpretação de Gonzaga executando o repertório selecionado.

\section{Considerações finais}

gual que nem fole de acordeão tipo assim num baião do Gonzaga

Chico Buarque, Tipo um baião, 2011

Observa-se que o baião, estilizado por Luiz Gonzaga a partir da década de 1940, tornou-se uma referência, um modelo, um formato, um dos fortes representantes da sonoridade nordestina, bem como um componente expressivo dentro do que convencionou-se chamar de música "tradicional", "de raiz" (NAPOLITANO, 2007) ou "regional" (FERRETTI, 1988). De acordo com MENEZES BASTOS (2007), o baião representa também a quinta "onda" mundial da música brasileira no plano internacional, constituindo um dos momentos em que a música brasileira alcançou visibilidade no exterior. Menezes Bastos ressalta que na década de 1950 o baião esteve presente no repertório de muitas orquestras e na trilha sonora de muitos filmes estrangeiros.

Espera-se que o material musical e os procedimentos aqui descritos e ilustrados possam complementar os estudos de caráter sociocultural que vêm sendo realizados sobre o baião de Gonzaga. Dessa forma, é possivel considerar que se trata de um objeto sonoro composto por um cruzamento de vários fatores, sendo que, do ponto de vista técnico-musical, temos um conjunto de elementos (figuras rítmicas, padrões de terças, notas repetidas, traços modais, etc.) que, quando combinados com a "levada", com timbres como o da sanfona, zabumba ou triângulo, e com a articulação peculiar, vão aproximar o ouvinte do tipo de baião que foi "canonizado" por Luiz Gonzaga.

A compreensão das combinações realizadas com esse material musical se mostra útil para estudantes de música 
e pode ser aplicada em disciplinas que visam "mostrar como se toca" o baião, seja para fins de interpretação, composição, arranjo, análise musical ou improvisação.

Tal abordagem acerca do baião de Luiz Gonzaga oferece subsídios mais palpáveis para que possamos mapear sua reutilização e ressignificação em diferentes momentos e cenários da música brasileira, a exemplo da "canção de protesto" da década de 1960, do "tropicalismo", da música instrumental produzida por compositores como Hermeto Pascoal e Egberto Gismonti, do cancioneiro brasileiro confeccionado a partir da década de 1970 até os dias atuais, e da produção instrumental contemporânea de artistas como Guinga, Hamilton de Holanda, André Mehmari, Carlos Malta, "Grupo Sa Grama" e "Trio Curupira", dentre muitos outros.

\section{Referências}

BAILEY, Derek. Improvisation: its nature and practice in music. Cambridge and New York: Da Capo Press, 1993.

CASCUDO, Luiz da Câmara. Dicionário do Folclore Brasileiro. Rio de Janeiro:

Instituto Nacional do Livro, Ministério da Educação e Cultura, 1962.

CÔRTES, Almir. Improvisando em Música Popular: um estudo sobre o choro, o frevo e o baião e sua relação com a "música instrumental" brasileira. 2012. 313p. Tese (Doutorado em Música) - Instituto de Artes, Universidade Estadual de Campinas, Campinas, 2012.

DIAS, Lêda. 0 acordeão e seus sotaques. In: Sotaques do fole / SESC, Departamento Nacional. Rio de Janeiro, 2011. p.10-30.

MENEZES BASTOS, Rafael José de. As contribuições da música popular brasileira às músicas populares do mundo: diálogos transatlânticos Brasil/Europa/África (segunda parte). Antropologia em primeira mão, Programa de Pós-graduação em Antropologia Social, Universidade Federal de Santa Catarina, Florianópolis, 2007.

FERRETI, Mundicarmo. Baião de dois: a música de Zé Dantas e Luiz Gonzaga no seu contexto de produção e sua atualização na década de 70. Recife: Fundação Joaquim Nabuco/Ed. Massangana, 1988.

FREITAS, Sergio Paulo Ribeiro de. Que acorde ponho aqui? Harmonia, práticas teóricas e o estudo de planos tonais em música popular. 2010. 859p. Tese (Doutorado em Música) - Instituto de Artes, Universidade Estadual de Campinas, Campinas, 2010.

GUERRA-PEIXE, César. Variações sobre o baião. 0 Tempo, São Paulo. 1954, ago.15. Disponível em: http://www.guerrapeixe.com/textos/texto17.html. Acesso em 20/05/2012.

NAPOLITANO, Marcos. A síncope das idéias: a questão da tradição na música popular brasileira. In: Coleção História do Povo Brasileiro. São Paulo: Fundação Perseu Abramo, 2007.

PIEDADE, Acácio Tadeu de Camargo. Jazz, música brasileira e fricção de musicalidades. Revista Opus, 11, 2005, p.197-207.

RAMALHO, Elba Braga. Luiz Gonzaga: his career and his music. Liverpool, 1997. 318p. Tese (Doutorado em Música). University of Liverpool.

ROCHA, Eder "o". s.d. Zabumba moderno. Pernambuco: Funcultura.

SANDRONI, Carlos. Feitiço decente: transformações do samba no Rio de Janeiro (1917-33). Rio de Janeiro: Jorge Zahar Editor/UFRJ, 2001.

SEVERIANO, Jairo. Uma história da música popular brasileira: das origens à modernidade. São Paulo: Ed. 34, 2008.

SILVEIRA, Mané. [Manoel Carlos de Campos Silveira] São Paulo, Brasil, 03 de nov. 2009. Entrevista concedida ao pesquisador Almir Côrtes.

SIQUEIRA, João Baptista. Influência ameríndia na música folclórica do Nordeste. Rio de Janeiro: Concurso de títulos e provas da E.N.M. da Universidade do Brasil, 1951.

TINÉ, Paulo José de Siqueira. Procedimentos modais na música brasileira: do campo étnico do nordeste ao popular da década de 1960. São Paulo, 2008. 196p. Tese (Doutorado em Música). Universidade de São Paulo.

TINHORÃO, José Ramos. Pequena História da música popular: da modinha à Canção de Protesto. Rio de janeiro: Editora Vozes, 1974.

VANDERLEY, Paulo. Discos. Disponível em <www.luizluagonzaga.mus.br>. Acessado em 20/03/2011.

\section{Notas}

1 Este artigo é parte da tese de Doutorado Improvisando em Música Popular: um estudo sobre o choro, o frevo e o baião e sua relação com a "música instrumental" brasileira (CÔRTES, 2012), que foi desenvolvida no curso de Doutorado em Música do Instituto de Artes da UNICAMP. Gostaria de agradecer à FAPESP (Fundação de Amparo à Pesquisa do Estado de São Paulo) por financiar esse trabalho através de bolsa de Doutorado (Processo 2006/06571-6).

2 Os discos de 78rpm da época possuíam classificações junto ao título da faixa, tais como "choro", "valsa", "samba", fox-trot, "toada", etc. É possível que tais denominações tenham sido inseridas pela gravadora em comum acordo com os intérpretes. 
3 Esse choro foi regravado por Jacob do Bandolim no disco Primas e bordões (RCA, 1962).

4 Na década de 1950, músicos ligados ao choro vão compor baiões, como o caso emblemático do Delicado de Waldir Azevêdo de 1950 e De Limoeiro a Mossoró de Jacob do Bandolim de 1956.

5 A discografia de Luiz Gonzaga encontra-se disponivel em: www.luizluagonzaga.mus.br. Acesso em 10 Abr. 2012. Gravações das composições comentadas ao longo do texto, assim como a maior parte da obra do sanfoneiro, podem ser consultadas nesse endereço eletrônico.

6 Para maiores detalhes acerca de Teixeira e Dantas conferir FERRETI (1988) e RAMALHO (1997).

7 Existem trabalhos que tratam de um tipo de baião anterior a Gonzaga. Pesquisadores como SIQUEIRA (1951), CASCUDO (1962) e TINHORÃO (1974) escreveram sobre o baião no contexto rural, apresentando hipóteses sobre as possiveis origens do vocábulo. 0 compositor e pesquisador Guerra-Peixe, por sua vez, chamou a atenção para as diferentes acepções do baião pelos estados do nordeste, apontando para diversas manifestações nordestinas que recebem a mesma denominação. Segundo GUERRA-PEIXE: "a palavra "baião" e suas derivadas traduzem [...] "alegria", "variação" e "vivacidade". E, ainda, "interlúdio", já que se intercala às falas do Bumba-meu-boi às manobras dos Cabocolinhos e se entremeia à poesia dos cantadores" (GUERRA-PEIXE, 1954).

8 Além de ter sido um dos principais campos de trabalho para os músicos, o rádio, juntamente com a indústria fonográfica, formatou a escuta e 0 padrão musical de toda uma época, especialmente a partir da década de 1930. De acordo com NAPOLITANO, "apesar da criação de várias estações até o início dos anos 1930 a música popular tinha mais espaço no circuito partitura-disco-teatro do que no rádio ou no cinema falado nascentes. Só a partir de 1932 o rádio foi uma espécie de "veículo sintese" da música popular, realizando três operações conjuntas: aglutinador de estilos regionais, disseminador dos gêneros internacionais e responsável pela "nacionalização" do samba, socializando para todo o Brasil o gosto musical carioca. Ao longo daquela década, o rádio e a vitrola substituíram, de uma vez por todas, o piano na sala da classe média brasileira" (NAPOLITANO, 2007, p.47).

9 Gravada em 1946 pelo grupo vocal Quatro ases e um coringa e regravada por Gonzaga em 1949.

10 Classificada como toada em 1947 e regravada como baião em 1952.

11 Tradução realizada pelo autor. Texto original: The rhythm, coming from the lively dances of the sertão, gained a new configuration with the introduction of the zabumba, the triangle and the accordion, that became the typical ensemble, instead of the original (viola, tambourine, botijão and rabeca) (RAMALHO, 1997, p.92).

12 Para mais detalhes sobre a execução da zabumba conferir o livro Zabumba moderno do músico Eder "0" Rocha.

13 Juazeiro compõe o lado A do mesmo disco de 78rpm que contém Baião.

14 Instrumentação recorrente nos grupos de choro, gravações de samba e programas de rádio da época. Os "regionais" eram compostos por um solista (flauta, clarinete, bandolim), violão 7 cordas, violão, cavaquinho e pandeiro, aparecendo esporadicamente o acordeom e outros instrumentos de percussão.

15 TINÉ (2008, p.98) considera que a inclusão de cadências tonais ao final de determinadas seções pode estar ligada à necessidade de adaptar o baião ao "gosto musical" da época.

16 Tradução realizada pelo autor. Texto original: The first stage - 1941-46 - revealed him as an interpreter and composer of Rio de Janeiro's popular repertoire, from Ernesto Nazareth to his own creation of mazurkas, choros, waltzes, polkas, sambas suitable for accordion. In the meantime he introduced several songs which did not belong to these common genres, those he brought from the sertão - like the xote, xamego, xaxado, miudinho, seridó, calango - a variety of dances very popular in sambas and forrós (RAMALHO, 1997, p.108-109).

17 Entendendo a capital aqui não apenas como o Rio de Janeiro, mas sim, dentro da idealização de um contraste rural/modal e tonal/urbano.

$18 \mathrm{Um}$ aspecto que chama a atenção no campo da harmonia é a presença do quarto grau com sétima menor em algumas tonalidades maiores, ou seja, um acorde no formato dominante, mas que não exerce tal função. Tal acorde aparece intercalado com o primeiro grau, como nos casos de Baião (Ex.8) e da introdução de Paraiba (Ex.20).

19 Expressão artística desenvolvida no nordeste, realizada normalmente por cantadores violeiros que improvisam versos sobre uma linha melódica pré-determinada.

200 modo hibrido chamado de mixolídio com quarta aumentada ou lídio com a sétima menor, presente nas melodias das cantorias, não foi encontrado nas composições de Gonzaga e parceiros.

21 Conferir os solos presentes nas gravações Pro Zeca de Victor Assis Brasil aos 6:17 minutos da faixa 1 do álbum Victor Assis Brasil ao vivo (Companhia Industrial de Discos, 1974) e Baião de Lacan de Guinga/Aldir Blanc aos 5:02 minutos da faixa 6 do álbum Bexiga (Sony/Eldorado, 2000) da banda Mantiqueira.

22 Entrevista concedida ao pesquisador em 2009.

23 Para maiores detalhes sobre improvisação "idiomática" conferir BAILEY (1993).

24 Dependendo do timbre selecionado ou por meio dos botões dos baixos, a sanfona produz notas oitavadas.

25 Ao chegar ao nordeste, a pequena sanfona de 8 baixos sofreu transformações pelas mãos de sanfoneiros que aprenderam a afinar o instrumento de maneira informal, dentre eles o pai de Luiz Gonzaga. Nesse processo artesanal, a afinação que antes era diatônica passou a ser cromática (conhecida como "afinação transportada") e veio a interferir também na técnica do instrumento (DIAS, 2011, p.25).

Almir Côrtes é multi-instrumentista de cordas dedilhadas (bandolim, violão, cavaquinho, guitarra e viola caipira), graduado em violão erudito pela UFBA (2003), Mestre (2006) e Doutor (2012) pela UNICAMP na área de Práticas Interpretativas. Foi um dos organizadores do V e VI "Encontro Nacional de Choro da UNICAMP" (2009/2010). Realizou estágio de um ano (2010/Programa PDEE-CAPES) como pesquisador visitante no Departamento de Jazz da Jacob's School of Music na Indiana University nos Estados Unidos. Possui dois CDs lançados e tem realizado concertos e oficinas no Brasil e no exterior, com especial destaque para sua participação nos eventos: Latin American Culture Celebration (2010), promovido pela Berklee School of Music e o Mandolin Symposium (2011/2012) na Universidade de Santa Cruz, Califórnia-EUA. Atua principalmente nos seguintes temas: música instrumental brasileira, música popular, choro, frevo, baião, improvisação, bandolim, guitarra e violão. Recentemente foi contemplado com bolsa da Fundação de amparo à pesquisa do Estado de São Paulo-FAPESP para desenvolver pesquisa de Pós-doutorado no Instituto de Artes da UNICAMP. 